\title{
The Representation of Emak-Emak (Indonesian Housewives) in Gojek Indonesia's Advertisement Titled Belanja di GoMart, Dibelanjain \#EmakJago!
}

\author{
Erol Kurniawan \\ Lecturer of English Literature of Faculty of Social Sciences and Humanities, Universitas Pakuan, Indonesia \\ http://dx.doi.org/10.18415/ijmmu.v8i4.2682
}

\begin{abstract}
As a product of pop culture, advertisement is intentionally designed to entice people to get interested in buying products and services, or even ideas. It also often utilizes local social-cultural phenomena that are close to our daily lives. This article will analyze the representation of emak-emak (housewives) in the video advertisement entitled Belanja di Gomart, Dibelajanin \#EmakJago (shopping in GoMart, guided by \#superbhousewives) released by Gojek Indonesia official YouTube Channel. In this advertisement, the notion of 'the power of emak-emak' is used in as the main concept to represent women in two different characters, the 'funny' and 'superb'. To feminist theorists, pop culture is always problematic for women as it strengthens the gender stereotypes putting them as either subordinate or inferior subjects. Additionally, scholars and Indonesian feminist activists have argued that the term emakemak has either derogatory or negative connotations. Using cultural studies perspective as well as textual analysis, this qualitative research aims at analyzing how these emak-emak are represented in the ad. At the end of discussion, I would argue that this ad serves to actually maintain and exercise the patriarchal ideology in terms of gender stereotypes.
\end{abstract}

Keywords: Representation; Pop Culture; Gender; Stereotypes; Advertisement

\section{Introduction}

In modern societies, it is almost impossible for people to avoid popular culture, such as advertising, media, films, and fashion. Why popular culture? Theoretically, popular culture is identical to the constitution of 'the people'. Hall argues that popular culture is the contested site for political construction of 'the people' and their relation to 'the power of bloc'. Additionally, it is also a site where the construction of everyday life is examined (Storey, 2018). Therefore, there is always a meaning to be politically delivered as well as constructed in the products of popular culture.

In this globalized world associated with the advancement of technology and information, media as a part of pop culture has a direct and straightforward message on its audiences. When watching television or surfing in the internet, we are unavoidably exposed to various advertisements which screen multiple representations. Therefore, everyday popular media materials will unconsciously affect people's 
lives. For instance, when we watch domestic or romantic dramas, we will be given references about and learn how neighbors, friends, and lovers interact. The same thing occurs when we learn the typical shape and content of friendships from films and TV (Gaunlett, 2002). It is also from pop culture and mass media where Indonesian women idealize 'whiteness' and are obsessed to become white through soap advertisement (Priyatna, 2013). Briefly, pop culture is inevitably relevant to the constitution of 'the people'.

Advertising is one of pop culture products which ideologically deals with the constitution of 'the people'. In the most obvious example, as part of modern societies people are inevitably exposed with a lot of advertisements when they access internet, online news, social media, or television in their everyday life. As one of the promotional tools, advertising is generally utilized to entice consumers to buy the goods, services, and ideas. To be able to successfully make a huge profit, advertisements are often inspired by ideas that are close to our society and presenting figures to get people interested in buying the products.

In many advertisements, women are often shown to sell products that may or may not be essentially related to them. Katharina (in Nagi, 2014) argued that women were generally depicted as 'sex' objects that were assumed to potentially catch people's attention or interest (Nagi, 2014). In relation to feminism perspective, advertisement, as a pop culture product, often strengthens and maintains cultural and gender stereotypes putting them as inferior or subordinate (Strinati, 2005).

In advertisements, women are represented in many different ways, but still in patriarchal frame. As stated by Astuti, in private television ads they were depicted as smart, beautiful, and knowledgeable housewives obliged to make their husband proud. These stereotypical qualities were then used by advertisers to help them sell their products (Astuti, 2016). She also argued that advertisements play an integral part in preserving as well as emphasizing the gender roles which are detrimentally harmful to women. They were creatively used as an effective medium to sell certain products such as beauty and household products.

\section{The Portrayal of Women in Advertising}

Advertising is the key part of popular culture and a reflection of social norms. In advertising, women have been treated as commodities. Moreover, women's bodies are often objectified to entice consumers to buy certain products. Objectification is the central notion to feminist theory. As cited from Stanford Encyclopedia of Philosophy, it refers to the seeing and/or treating a person, usually a woman, as an object. At this point, the focus is primarily on sexual objectification as it occurs in the sexual realm (Stanford Encyclopedia of Philosophy, n.d.).

In addition, advertising, marketing, and fashion industry have also created certain qualities or beauty standards which seem to not actually exist in real world. A woman should be 'reasonably' good looking and must have long hair, white skin, smooth and shapely legs, slim waist, shining white teeth, and etc. Murwani argued that through WRP (a diet or weight loss product) ad, industries hold an important role in constructing the concept of an 'ideal' woman in terms of her physical appearance. In other words, these beauty myths are just qualities that are created based on male's perspectives (Muwarni, 2010).

Besides objectifying women's bodies, advertisements are also often presenting them as subjects that are good at dealing with household chores. In other words, the gender-biased cultural signs and female domestication are also often seen in some television ads. Ironically, while women are represented as a mother or wife that is good at dealing with household chores and taking care of their children, ads mostly depict the success of men in the public. A case study conducted by Siswati (2019) in Malang shows that women agree with the representation of female domestication in the domestic sector that is

The Representation of Emak-Emak (Indonesian Housewives) in Gojek Indonesia's Advertisement Titled Belanja di GoMart, Dibelanjain \#EmakJago! 
screened in advertisements. They see it as the 'nature' of women and the reflection of women themselves. Nevertheless, just like men, they also demand to be represented as female subjects who can succeed in the public areas (Siswati, 2019). Even though the representation of women in advertising has shifted from time to time, it seems that portraying women in domestic area is still popular until now.

As quoted by Nicola Kemp (2017), Karin Kihlberg examined the evolution of women role model in advertising and she mentioned at least six common stereotypes ranging from the domestic obsessive to sex object (Kemp, 2017). In advertising women are often unnaturally energized by the issues to do with home (often cleaning) and screened as a selfless nurturer, a busy working mother with too much to do (usually frustrated and unhappy), sex object, and an unattainable goddess to be projected as a physically perfect object of desirability. To sum up briefly, it can be inferred that what's been argued by Kihlberg suggests that all those stereotypes are still used to glue women to domestic sector.

In Indonesia, Belanja di Gomart, Dibelajanin \#EmakJago (shopping in GoMart, guided by 'superb' mother) is one advertisement which portrays women in domestic sector, specifically household chores. Officially released by Gojek Indonesia YouTube channel November $30^{\text {th }} 2020$ and viewed by 12,268 people until April 2021, this video advertisement highlights the social phenomenon called the power of emak-emak (housewives). Directed by one of the famous Indonesian directors, Dimas Djayadinigrat, this advertisement is trying to use the popular notion called 'the power of emak-emak' to promote GoMart, a service by Gojek (an online transportation service) which helps people buy daily needs online. Gojek's driver will buy items we order at the nearest store partner and deliver them to our home. In the advertisement, 'smart' and 'superb' housewives will help us select items with the best quality.

Other representation of women is also shown in the beginning of this advertisement. Obviously different from the depiction of 'smart' and 'superb' housewives, these women are represented as funny, illogical, careless, and uncontrollable mothers who can do anything they like without having to worry much about the consequences they might encounter. Starting from this female portrayal, this study aims at analyzing how women are represented in this advertisement. Besides that, as it is produced by a male director, another purpose of this study is to see how women is seen through male perspective.

\section{Research Methodology}

This study examines how women are represented in the advertisement titled Belanja di Gomart, Dibelajanin \#EmakJago (shopping in GoMart, guided by 'superb' mother). Additionally, this study is also trying to analyze how women are constructed through male perspective and reveal the underlying message of the hashtag \#emakjago ('superb' housewives) used in the title of the advertisement.

The textual analysis will be taken to reveal how the cultural hegemony is exercised and maintained through the woman representation in the advertisement Belanja di Gomart, Dibelajanin \#EmakJago. Besides that, several cinematic elements such as the dialog, characterization, as well as the contextual setting will also be the focus of this analysis to see how the gender stereotypes are attributed to women.

Cultural studies approach will also be utilized in this analysis to reveal dominant power that is being exercised through this women representation in the advertisement. As stated by Chris Barker, as a critical perspective cultural studies examines the cultural phenomenon and its relation to power (Barker, 2000). Additionally, it also examines power and culture to see how the representation cannot be politically separated from the cultural hegemony that is being maintained by certain social force.

The Representation of Emak-Emak (Indonesian Housewives) in Gojek Indonesia's Advertisement Titled Belanja di GoMart, Dibelanjain \#EmakJago! 
Several key concepts will be used to help understand the social and cultural phenomenon being observed. The first concept is 'representation' which refers to a set of processes by which signifying practices appear to stand for or depict another object or practice in the 'real' world (Barker, 2004). It also suggests the symbolical act which reflects an independent object world. In cultural studies perspective, representations are constitutive of the meaning of that which they purport to stand in for. Moreover, it does not involve correspondence between signs and objects but also creates the representational effect of realism.

Intrinsically, the representation is inseparable from questions of power as it has got the potential to provide some kinds of knowledge to exist and exclude other ways of seeing (Barker, 2004). Consequently, representation is political because it brings us to a question what does it mean to be a woman, man, gay, straight, mother, father, and so forth? Understanding an 'essential' state of being can only be understood through representation as it has to be represented and learned. Therefore, to complicate things further, Stuart Hall (in Barker, 2004) speaks about the politics of representation which inquiries into power relations which creates certain identity while simultaneously deconstructs it.

Another concept used in this analysis is gender. This notion refers to the cultural assumptions and practices which govern the social construction of men, women, and their social relation. Gender ideology spells out expectations of how men and women should behave according to their ascribed sex (Blackburn, 2004). Speaking about gender will introduce us to the cultural notions, femininity and masculinity. These forms of gender are the outcome of the cultural regulation of behaviours regarded as socially appropriate to a given sex.

Barker (2004) adds that since gender is a matter of culture rather than 'nature', it is always a matter of how men and women are represented. Additionally, affirming sex or gender distinction actually suggests that the actual physical or mental effects of biological differences have been exaggerated to maintain a patriarchal system of power. Consequently, it creates a consciousness among women that they are naturally better suited to domestic roles (Whelehan, 2004).

Discussion about gender is actually inseparable from patriarchal ideology. In their book entitled 50 Key Concepts in Gender Studies, Jane Pilcher and Imelda Whelehan state that in feminist perspective, patriarchy refers to the fundamentally social system of masculine domination over women. It is associated with the bases of women's subordination to men. Meanwhile, Bell Hooks defines patriarchy as a politicalsocial system which insists that males are inherently dominating, superior to everything and everyone deemed weak, especially females, and endowed with the right to dominate and rule over the weak and to maintain that dominance through various forms of psychological terrorism and violence (Hooks, 2010).

All these key concepts will be utilized to analyse the representation of women in the advertisement Belanja di Gomart, Dibelajanin \#EmakJago. This study then will try to dismantle the dominant ideology being exercised. With the hashtag \#EmakJago ('superb' housewives) which seems empowering to women, this analysis will offer a critical and reflective question. Is it really empowering women or just reinforcing the gender stereotypes in patriarchal point of view?

\section{Analysis and Discussion}

\section{Women in Belanja di Gomart, Dibelajanin \#EmakJago Advertisment}

Belanja di Gomart, Dibelajanin \#EmakJago is the advertisement released by Gojek Indonesia YouTube Channel and directed by an Indonesian famous director Dimas Djayadiningrat $30^{\text {th }}$ November 2020 during the Covid-19 outbreak. This one-minute and ninety-second ad tells about the lives of emakemak (housewives) that seem to be very common to be found in Indonesia. Emak-emak (or emak in its 
singular form) has been quite popular recently yet been debated in media. To Indonesian feminists the term has derogatory connotations (Afrianty, 2018). Emak-emak's role is usually confined to household work. There are some popular images showing that these emak-emak are very uncontrollable, as riding a motorcycle without a helmet, confidently reprimanding the police officer severely even though they are caught to have broken the traffic rules, and other similar extremely illogical actions.

The ad begins when a male news anchor informs us about the social phenomenon entitled fenomena emak-emak (the phenomenon of housewives). These emak-emak are screened in different representations, but mostly with bad, negative, and careless attitudes. In the beginning of the ad, these housewives are depicted to be very confident and proud to perform their illogically unacceptable actions. They are also very confident and proud to say "enak jadi emak-emak, lampu merah gue omelin jadi ijo" (I'm proud to be emak-emak, once we get angry. Then, we are free to pass the red traffic light). In this scene, they are depicted as careless subjects who are proud of doing dangerous actions. In Indonesia, it is common to find emak-emak who like to break the rules when they ride a motorcycle or drive a car. They will often be angry if the policeman stops and fines them.

As the ad continues, it presents several images of emak-emak which seem to be very related in daily life. There is an emak suddenly throwing a bucket of water to a man who is spraying insecticide. She innocently does that because she thinks there's a fire in the neighborhood. Surprisingly, instead of asking forgiveness to the man, she leaves the man without feeling guilty of what she has done to him. Another scene shows an emak making fried bananas in the kitchen. The shocking thing is when she takes the fried banana using her bare hand while it is still being cooked in the frying pan with hot cooking oil. She confidently says that she does it to make cooking seem easy, quick, and effective.

The next screen shows an emak in arisan (gathering). In Indonesia, it is quite common for emakemak to get together in arisan held usually once a month, especially those living in kampung (village). In general, arisan involves informal credit and saving scheme in a form of lots, besides social interaction among group members. It is usually held at the houses of group members. The host usually provides some food and snacks. In this ad, an emak is seen to have taken and put some snacks into her bag. She takes the food and snacks home for her family.

Another scene shows an emak is starting the motorcycle engine which produces excessive smoke and causes air pollution. She seems not to care even people behind her are affected by her unacceptable action. She even simply blames them for standing behind her while starting the engine. The last scene shows an emak playing volleyball game. She hits the ball using her foot instead of using her hand. She then laughs and feels very proud of doing that spontaneously.

At the beginning of this ad, emak-emak are represented as funny subjects as they do 'out of the box' things which seem 'illogically unacceptable'. The male news anchor clearly says 'terkadang mereka terasa salah, dan kita gagal paham' (sometimes they are wrong, and we fail to understand). The statement can be understood an effort to say that these women are identical to illogical things. In patriarchal society, women are considered as inferior, and subordinate subjects who rely on their feelings instead of their logic. They are also identical to household work. therefore, it is clear that these representational images can be said as an effort to emphasize the stereotypes attributed to them.

The 'illogically unacceptable' actions that these emak-emak do are also intended to give the humorous effects on the ad. It can also be inferred as an attempt to make fun of women who are proud of their 'embarassing' actions. Symbolically, this ad serves as a medium which tells that these emak-emak are illogically uncontrollable and unacceptable because they like to do 'inappropriate' things without thinking about the consequences. 
Julia Suryakusumah, in her reading of a short movie tilik which tells a group of emak-emak from a village ride in the back of an open truck, argues that portraying women like this implies that in our collective consciousness we do not actually respect women (Suryakusuma, 2020). This representation also reinforces the gender stereotypes and stereotypes women negatively. Additionally, this ad also shows how women are seen in male perspective. Conceptually, the camera angles, and the big close-ups of the women's face which are intended to emphasize their character defects. In other words, the director is unconsciously trying to put women down.

It is also important to look at the male news anchor's facial expression. When he reads out the news, he seems to look really hopeless and stressed out with the news content highlighting the phenomenon of emak-emak. He feels hopelessly embarrassed to inform us about the illogical actions that emak-emak have done. Furthermore, it is also interesting to note that in other scene, there's a man's voice laughing at an emak taking and putting snacks into her bag during arisan. In critical reading, it can be inferred that men are trying to put women down by making fun of their 'embarrassing' actions.

In the second part of the ad, these emak-emak are compared to two images of women, a 'smart' woman who is good at shopping and buying daily need and a 'warm' looking housewife. Their representation is totally far different from other emak-emak in the beginning of the ad. One emak is presented as a neat woman wearing an apron and ready to help you pick best quality items while other woman is presented a warm looking mother who is technology literate as she orders things using GoMart online application. Actually, these representational images imply that women are still glued to domestic sector and household work.

The reinforcement of gender roles is again seen from the male narrator saying that untuk urusan belanja mereka tidak pernah salah. Belanja sayur, daging, ikan, buah, mereka ahlinya. (for shopping, they (emak-emak) are never wrong. They are very expert at buying vegetables, meat, fish, and fruits). This statement informs us that buying daily needs can only be done by emak-emak instead of seeing it as a basic skill that everyone must have and learn. Meanwhile, the woman who orders daily needs using GoMart application also confirms that shopping is really close and identical to women. As suggested by Strinati, for feminist theories, pop culture serves as a medium to politically maintain and reinforce the gender stereotypes harmful to women.

Unlike emak-emak who are proud to celebrate their illogically unacceptable and extreme actions, these two women are represented in different way. They seem to be presented in a more 'positive' way, one is good for being a well-experienced shopper and other is a calm housewife coming from upper social class. Nevertheless, this women representation implies what Mies (19982) suggests as housewifization. A notion which domesticates and defines women as housewives who always deals with household work (Suryakusuma, 2011). In short, no matter what the representations are, this Gojek ad is still trying to culturally associate women with domestic as well as household work.

Briefly, it can be said that through these ad women are divided into two different categories. The first one refers to a group of emak-emak who are proud of their 'extreme' and illogical actions. In this category, they are made of fun to relate the viewers to 'reality' where it already becomes a common sense that emak-emak often make mistakes and do not seem to care of the consequences. Through this kind of representation, this ad is actually trying to associate most emak-emak with these bad attitudes though in reality it does not generalize Indonesian housewives. Many Indonesian feminists does not agree with the use of the derogative term emak-emak as it has bad connotations. The Indonesian women congress even denounced the term and declared preference on ibu bangsa (mothers of nation) to call Indonesian mothers. It is true that there are often emak-emak in our midst as presented by this ad, but it is also misleading if this representation dominantly depicts Indonesian women in mass media because the term

The Representation of Emak-Emak (Indonesian Housewives) in Gojek Indonesia's Advertisement Titled Belanja di GoMart, Dibelanjain \#EmakJago! 
referring to the characteristics of emak-emak constructed in patriarchal ideology can be understood as the 'taken for granted' attributes by our society to judge Indonesian housewives.

The second category of emak-emak is also problematic. Representing emak jago (superb housewife) which seems empowering is actually again reinforcing the gender roles which place women in domestic area. Still under patriarchy, they are again associated with household work. It is obvious that though the use of \#emakjago hashtag seems to give credits to women good at household work, it is apparently only an attempt to justify that dealing with domestic sector is part of woman's 'nature'. In other words, patriarchy as a cultural hegemony still holds a dominant power over women.

\section{Conclusion}

As a popular culture product, advertisement plays an integral part in maintaining the cultural hegemony. At some point, advertisement is not only entertaining, but also containing political agenda which reinforces an ideology along with its particular stereotypes. Belanja di Gomart, Dibelajanin \#EmakJago is an ad released by Gojek Indonesia YouTube channel which highlights the life of emakemak in daily life. Directed by a male director, this ad represents women in his perspective. The study shows that besides representing women as subjects associated with household work and domestic sector, this ad also serves as a medium to emphasize the gender stereotypes of women. That most of Indonesian housewives are often associated with bad attitudes such as breaking the rules and doing some illogical or embarrassing actions is strongly asserted through this ad.

Meanwhile, the ad also screens other representation of Indonesian housewives. Two women are considered as emak jago (superb housewives), a credit given to a well-experienced housewife that is good at shopping and selecting best quality items. Nevertheless, this representation does not really empower women because they are still presented as subjects who are good at household work. As expected by patriarchal society, a good housewife must be good at domestic sector such as shopping, cooking, and nurturing. Therefore, this ad is actually produced to strengthen as well as exercise the patriarchal ideology and the gender stereotypes that are detrimentally harmful to women. Through this ad, our society is not only given notions about the bad attitudes of Indonesian emak-emak as a common sense, they are also asked to confirm that dealing with household work is part of women's 'nature'.

\section{References}

Afrianty, D. (2018). The Power of Emak-Emak: Empowering or patronising Indonesian Women? https://indonesiaatmelbourne.unimelb.edu.au/the-power-of-emak-emak-empowering-or-patronisingindonesian-women/

Astuti, Y. D. (2016). MEDIA DAN GENDER (Studi Deskriptif Representasi Stereotipe Perempuan dalam Iklan di Televisi Swasta. Profetik Jurnal Komunikasi, 9(2), 25-32.

Barker, C. (2000). Cultural Studies: Theory and Practice. Sage Publication.

Barker, C. (2004). The Sage Dictionary of Cultural Studies. Sage Publications.

Blackburn, S. (2004). Women and The State in Modern Indonesia. Cambridge University Press.

Gaunlett, D. (2002). Media, Gender, and Identity: An Introduction. Routhledge. 
Hooks, B. (2010). Understanding Patriarchy. Louisville Anarchist Federation.

Kemp, N. (2017). Six Stereotypes of Women in Advertising. https://www.campaignlive.co.uk/article/sixstereotypes-women-advertising/1426391

Muwarni, E. (2010). Konstruksi ‘Bentuk Tubuh Perempuan' Konstruksi ‘Bentuk Tubuh Perempuan' Dalam Iklan Televisi. Jurnal Ilmu Komunikasi, 2(1), 10-18.

Nagi, P. (2014). Projection of Women in Advertisement: A Gender Perception Study. International Journal of Managerial Studies and Research (IJ, 2(9), 75-88.

Priyatna, A. (2013). Becoming White (Fitria Mayasari (Ed.)). Matahari.

Siswati, E. (2019). Women's attitude towards representation of women domestication in advertisement. Masyarakat, Kebudayaan Dan Politik, 32(1), 80-94.

Stanford Encyclopedia of Philosophy. (n.d.). Retrieved April 7, 2021, from https://plato.stanford.edu/index.html

Storey, J. (2018). Cultural Theory and Popular Culture An Introduction (Eigth). Pearson Longman.

Strinati, D. (2005). An introduction to Theories of Popular Culture (Second). Routhledge.

Suryakusuma, J. (2011). State Ibuism. The Social Construction of Womanhood in New Order Indonesia. Komunitas Bambu.

Suryakusuma, J. (2020). “Tilik”, Sexist Stereotypes and Our Collective Insanity. The Jakarta Post.

Whelehan, J. P. \& I. (2004). 50 Key Concepts in Gender Studies. Sage Publications.

\section{Copyrights}

Copyright for this article is retained by the author(s), with first publication rights granted to the journal.

This is an open-access article distributed under the terms and conditions of the Creative Commons Attribution license (http://creativecommons.org/licenses/by/4.0/). 